\title{
EFFECT OF DIFFERENT FOREST MANAGEMENT PRACTICES ON THE SOIL MACROFAUNA IN THE ARBOREAL CAATINGA ${ }^{1}$
}

\author{
PRISCILA SILVA MATOS ${ }^{2}$, PATRÍCIA ANJOS BITTENCOURT BARRETO-GARCIA ${ }^{3 *}$, RAFAEL NOGUEIRA \\ SCORIZA $^{3}$
}

\begin{abstract}
Forest management can lead to numerous changes of different magnitudes in the composition and diversity of soil organisms, according to the level of interference with the habitat. Within this context, this study aimed to test the influence of different types of forest management on the edaphic macrofauna community in a region of arboreal Caatinga. The study was carried out in Contendas do Sincorá National Forest, Contendas do Sincorá - Bahia. The experimental area consisted of three types of management (clear cutting, selective cutting by diameter at breast height and selective cutting by species), and a condition of unmanaged Caatinga, which was used as control. The macrofauna was sampled twice a year (March and November) using the soil monolith method. Densities, total number of individuals, total richness, average richness, and Shannon and Pielou rates were estimated. The soil macrofauna was shown to be sensitive to different forest management practices, which indicates that selective cutting is a more conservative system to manage the Caatinga. Among these, selective cutting by species proved to be less impacting on the soil macrofauna, providing more expressive diversity and abundance indexes, and the occurrence of more demanding organisms in microclimate conditions, characteristic of preserved areas. The predominant groups of edaphic fauna, both in the unmanaged as in managed Caatinga, were Isoptera, Formicidae, Chilopoda, and Coleoptera Larvae.
\end{abstract}

Keywords: Soil organisms. Sustainable exploration. Diversity of invertebrates.

\section{EFEITO DE DIFERENTES PRÁTICAS DE MANEJO FLORESTAL SOBRE A MACROFAUNA EDÁFICA EM CAATINGA ARBOREA}

\begin{abstract}
RESUMO - O manejo florestal pode acarretar inúmeras modificações na composição e diversidade dos organismos do solo, em diferentes magnitudes de acordo com o nível de interferência no habitat. Neste contexto, o objetivo deste estudo foi testar a influência de diferentes tipos de manejo florestal sobre a comunidade da macrofauna edáfica em área de Caatinga arbórea. O estudo foi realizado na Floresta Nacional Contendas do Sincorá, Contendas do Sincorá - BA. A área experimental foi constituída de três tipos de manejo (corte raso, corte seletivo por diâmetro e corte seletivo por espécie) e uma condição de Caatinga não manejada, que foi utilizada como controle. A macrofauna foi amostrada pelo método do monólito de solo, em duas épocas do ano (março e novembro). Foram estimadas as densidades, o número total de indivíduos, a riqueza total, a riqueza média e os índices de Shannon e de Pielou. A macrofauna do solo mostrou-se sensível às diferentes práticas de manejo florestal, sendo indicativa de que os cortes seletivos são sistemas mais conservacionistas de uso da Caatinga. Dentre esses, o corte seletivo por espécie mostra-se menos impactante à macrofauna do solo, proporcionando índices de diversidade e abundância mais expressivos e a ocorrência de organismos mais exigentes em condições de microclima, característicos de áreas preservadas. Os grupos predominantes da fauna edáfica, tanto na Caatinga não manejada quanto na manejada, foram Isoptera, Formicidae, Larvas de Coleóptera e Chilopoda.
\end{abstract}

Palavras-chave: Organismos do solo. Exploração sustentável. Diversidade de invertebrados.

\footnotetext{
${ }^{*}$ Corresponding author

${ }^{1}$ Received for publication in $04 / 06 / 2018$; accepted in $05 / 02 / 2019$

Extracted from the first author's Masther's dissertation.

${ }^{2} \mathrm{PhD}$ student in Soil Science, Universidade Federal Rural do Rio de Janeiro, Seropédica, RJ, Brazil; priscilamatos2008@hotmail.com ORCID: 0000-0002-5037-2078.

${ }^{3}$ Department of Agricultural Engineering and Soil, Universidade Estadual do Sudoeste da Bahia, Vitória da Conquista, BA, Brazil; patriciabarreto@uesb.edu.br - ORCID: 0000-0002-8559-2927, rafaelscoriza@gmail.com - ORCID: 0000-0001-7361-4095.
} 


\section{INTRODUCTION}

The caatinga biome is considered exclusively Brazilian, in view of the set of biological resources and conditions found there (DRUMOND; SCHEISTEK; SEIFFARTH, 2012). Despite this and its importance, the biome has been severely deforested in recent years, and is currently represented by about $46 \%$ of its original area. Among the main causes for this devastation is the illegal wood extraction to produce firewood and coal, which represents $80 \%$ of the demand for timber resources in the Northeastern region (MMA, 2018).

Within this context, sustainable forest management (SFM), provided for in the legislation in force in Brazil (Law no. 12.651, of May 25, 2012), presents itself as an important solution to explore resources in a sustainable way, for it consists of the rational management in forest use, aiming to reach economic, social, and environmental benefits, respecting the ecosystem sustaining mechanisms, and considering the use of multiple species (timber or not) (BRASIL, 2012). This practice is based on the resistance and resilience properties when facing a disturbance; meaning, in the ability the ecosystem has to avoid changes, and in the time it takes to return to its original state (SMITH; SMITH, 2001).

The identification of the most appropriate forest management system for the reality of the Caatinga biome is fundamental to ensure its recovery after anthropic interventions. In this perspective, the description of ecological indicators, such as the community of soil invertebrates, will allow us to understand the level of disturbance caused by the type of management adopted (MOÇO et al., 2005), and to provide subsidies to select more appropriate managements.

Changes in vegetation, especially in the factors related to forest dynamics, can significantly affect the abundance and diversity of soil invertebrates (BARETTA et al., 2007). Removal of vegetation, for example, can reduce the protection of the soil against climatic variations, causing high insolation, high temperatures, and low humidity; which renders the edaphic environment less favorable to the survival and reproduction of organisms (GUERRA; BUENO; SCHUBART, 1982). Therefore, soil invertebrates have been commonly used as ecological indicators, as they can reflect changes in the environment (physical, chemical, or biological) and, therefore, indicate how much a management practice can alter the characteristics of the environment.

In Brazil, studies were carried out on the response of edaphic fauna to the vegetation dynamics in different biomes, such as Atlantic Forest, Cerrado, Amazon, and Pampa (MOÇO et al., 2005; SILVA et al., 2006; BARETTA et al., 2007; MARCHÃO et al., 2009; SCORIZA; CORREIA, 2016, HOFFMAN et al. 2018, COSTA; DRESCHER, 2018). However, records of studies on the subject Caatinga biome are still few (NUNES; ARAÚJO FILHO; MENEZES, 2008; SOUTO et al., 2008; NUNES; ARAÚJO FILHO; MENEZES, 2009; ARAÚJO et al., 2009), especially in areas under forest management. We assume, therefore, that the forest management, according to its level of interference on the Caatinga, entails different magnitudes of changes in the edaphic macrofauna structure and composition.

\section{MATERIAL AND METHODS}

The current study was developed in Contendas do Sincorá National Forest (Floresta Nacional, FLONA), in an area of arboreal Caatinga, classified as Forested Stepic-Savannah (MARTINS, 2012), where the following species are frequent Myracrodruon urundeuva, Schinopsis brasiliensis, Tabebuia sp., Aspidosperma pyrifolium, and Cereus jamacarus (LIMA; LIMA, 1998). FLONA is in the municipality of Contendas do Sincorá, state of Bahia, and was established in September 1999, after a long history of logging for the production of charcoal. It is located at $13^{\circ} 55^{\prime} 21^{\prime}$ ' South latitude and $41^{\circ} 06^{\prime} 57^{\prime}$ ' West longitude, and corresponds to an area of 11,034 hectares.

The region's altitude varies between 295 and 380 meters. The local climate is semiarid, with an average annual temperature of $23{ }^{\circ} \mathrm{C}$, and an annual rainfall between 596 and $679 \mathrm{~mm}$ (MMA, 2006). Check Figure 1 for the monthly rainfall data (collected using a pluviometer) provided by the municipality of Contendas de Sincorá.

The experimental area consisted of four managements, which corresponded to three types of management and an unmanaged Caatinga condition. The managements adopted were: a) clear cutting (corte raso, CR) - all trees and shrubs are cut; b) selective cutting by minimum diameter (corte seletivo por diâmetro mínimo, CSDap) - felling of all trees with diameter at breast height $(\mathrm{DBH})$ greater than or equal to $5 \mathrm{~cm}$; c) selective cutting by species (corte seletivo por espécie, CSE) - felling trees of three species with higher occurrence in the area (Commiphora leptophloeos (Mart.) J. B. Gillett, Jatropha molissima (Pohl) Baill, and Pseudobombax simplicifolium A. Robyns); and d) control (C) unmanaged Caatinga. 


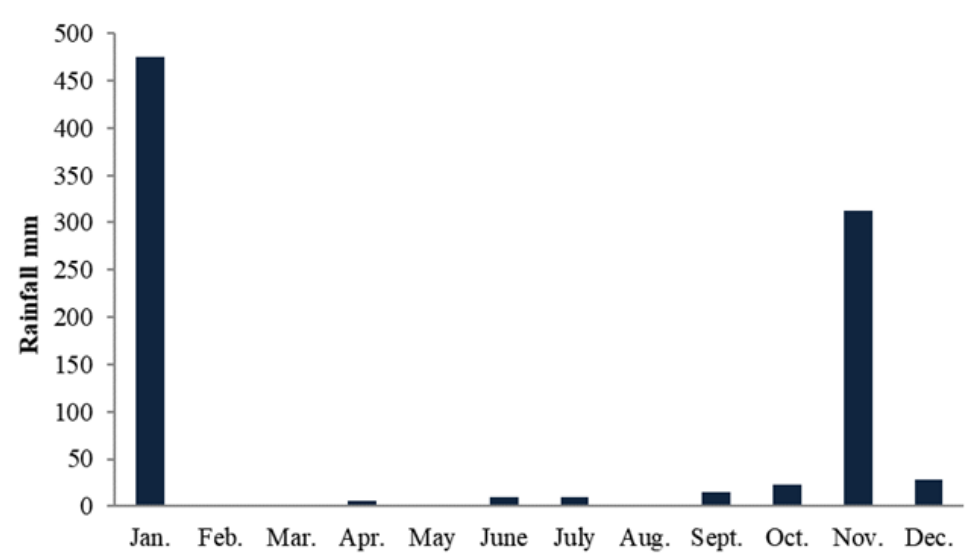

Figure 1. Monthly rainfall in Contendas do Sincorá (BA) in 2016.

The selection of the most appropriate area for the experiment followed the criteria established in the Caatinga Forest Management Network Protocol (Protocolo da Rede de Manejo Florestal da Caatinga) (RMFC, 2005). In the FLONA, two experimental units with the same edaphoclimatic characteristics were defined, with a maximum distance of 150 meters from one another. In each experimental unit, four plots measuring $20 \times 20 \mathrm{~m}\left(400 \mathrm{~m}^{2}\right)$ were delimited for each management, with a total of 16 plots. They were distributed at random and spaced apart by approximately one meter. Together the two units totaled eight replicates (plots) per management.
The forest management was carried out in May 2015, removing all woody material and maintaining harvest residues (thin branches, leaves, and bark) in the managed areas.

The soil of the studied area is classified as Red-Yellow Argisol (MMA, 2006), and presents chemical characteristics (depth $0-10 \mathrm{~cm}$ ) as found in Table 1 . The analyzes for this characterization were performed according to Donagemma (2011): $\mathrm{pH}$ (water); extractable $\mathrm{P}$ and $\mathrm{K}$ by Mehlich $^{-1}$; exchangeable $\mathrm{Ca}, \mathrm{Mg}$, and $\mathrm{Al}$ by $\mathrm{KCl} 1 \mathrm{~mol} \mathrm{~L}^{-1}$; organic matter $(\mathrm{OM})$ by oxidation with $\mathrm{Na}_{2} \mathrm{Cr}_{2} \mathrm{O}_{7} 4$ N.

Table 1. Chemical characterization of the $0-10 \mathrm{~cm}$ layer of soil in managed and unmanaged arboreal caatinga.

\begin{tabular}{ccccccccccccc}
\hline Management & $\mathrm{pH}$ & $\mathrm{CO}$ & $\mathrm{P}$ & $\mathrm{K}$ & $\mathrm{Ca}$ & $\mathrm{Mg}$ & $\mathrm{Al}$ & $\mathrm{H}$ & $\mathrm{SB}$ & $\mathrm{CTC}$ & $T$ & $\mathrm{~V}$ \\
\hline & & $\%$ & $\mathrm{mg}_{\mathrm{dm}}{ }^{-3}$ & & $----------------------\mathrm{cmol}_{\mathrm{c}}$ & $\mathrm{dm}^{-3}-----------------------$ & & $\%$ \\
$\mathrm{CR}$ & 6.08 & 13.40 & 3.28 & 0.22 & 3.71 & 1.81 & 0.08 & 1.97 & 5.88 & 5.96 & 7.93 & 72.97 \\
$S$ & 0.11 & 1.69 & 0.22 & 0.03 & 0.52 & 0.21 & 0.03 & 0.24 & 0.66 & 0.64 & 0.55 & 3.66 \\
\hline CSDap & 6.08 & 12.93 & 2.91 & 0.19 & 3.44 & 1.92 & 0.05 & 2.10 & 5.57 & 5.62 & 7.69 & 71.50 \\
$S$ & 0.11 & 1.49 & 0.81 & 0.03 & 0.31 & 0.20 & 0.04 & 0.18 & 0.43 & 0.41 & 0.33 & 3.41 \\
\hline CSE & 5.99 & 12.10 & 2.69 & 0.22 & 3.35 & 1.72 & 0.08 & 2.09 & 5.28 & 5.35 & 7.44 & 70.34 \\
$S$ & 0.13 & 1.40 & 0.44 & 0.06 & 0.34 & 0.25 & 0.09 & 0.14 & 0.61 & 0.54 & 0.56 & 4.63 \\
\hline C & 6.14 & 12.50 & 3.25 & 0.19 & 3.71 & 1.87 & 0.07 & 2.02 & 5.77 & 5.84 & 7.86 & 72.55 \\
$S$ & 0.10 & 1.56 & 0.44 & 0.03 & 0.34 & 0.20 & 0.04 & 0.22 & 0.46 & 0.43 & 0.43 & 3.44 \\
\hline
\end{tabular}

Abbreviations: CR, clear cutting; CSDap, selective cutting by DBH; CSE, selective cutting by species; C (control), unmanaged Caatinga, witness; $S$, standard deviation for $\mathrm{n}=8 ; \mathrm{pH}$, ionic hydrogen potential; $\mathrm{SB}$, sum of exchangeable bases; CTC, effective cation exchange capacity; $T, \mathrm{CTC}$ at $\mathrm{pH} 7.0$; V, base saturation; $\mathrm{CO}$, organic carbon.

Soil collection to capture the fauna was performed in March 2016 (1st period - 300 days after the management) and November 2016 (2nd period 540 days after management). The 1 st period was marked by the absence of rain falling events, with no record of rain during March and the previous month. The 2nd period was characterized by a cumulative rainfall of $300 \mathrm{~mm}$ in November and the occurrence of less intense rain in the previous month (Figure 1). Each plot constituted a collection point, with at least five meters distance between the points, totaling 32 sampling points. The macrofauna was sampled using the method recommended by Tropical Soil Biology and Fertility (TSBF) (ANDERSON; INGRAM, 1993) with depth adaptation. Therefore, soil monoliths $25 \times 25 \mathrm{~cm}$ wide and $10 \mathrm{~cm}$ deep were collected. Afterwards, manual sorting was performed, with the aid of a white tray, where organisms visible to the naked eye were collected and stored in plastic bottles containing $70 \%$ alcohol 
solution for preservation. Subsequently, the organisms were identified in large groups, such as class, subclass, and order, according to Ruggiero et al. (2015).

The number of individuals for each group and the total number of individuals per management and period were estimated by extrapolating the averages for individuals per $\mathrm{m}^{2}$. We also calculated the total richness, average richness; and the Shannon-Weaver index (H') and Pielou equability index (J) (ODUM; BARRETT, 2011), were used to evaluate the domain of faunistic groups and biological diversity in the studied areas.

The data collected was tested regarding homogeneity (Cochran e Barttlet, $5 \%$ ) and normality (Lilliefors, $5 \%$ ). After verifying the data non-normality and homogeneity, we used nonparametric tests of Kruskal-Wallis, to compare the treatments, and Wilcoxon test, to compare the periods, with a $5 \%$ significance, using the software $\mathrm{SAEG}{ }^{\circledR}$ v.9.1. In cases with significant variation, letters were inserted to represent the differences between managements (Table 2). As a complement, in order to evaluate the similarity of the macrofauna community between treatments in each collection period, we analyzed the main components (software Canoco $^{\circledR}$ v.4.5).

\section{RESULTS AND DISCUSSION}

Considering the set of treatments studied, we found 378 individuals during the 1st period and 632 during the 2 nd period, distributed in 18 and 20 taxonomic levels, respectively (Table 2). In the control area (unmanaged arboreal Caatinga) we identified 16 taxonomic groups during the 1 st period and 18 during the 2 nd period. The numbers of taxonomic groups observed were higher than those found by Nunes, Araújo Filho and Menezes (2009) in Caatinga preserved in the state of Ceará (14 taxa), and by Marchão et al. (2009) in the Cerrado, region of Correntina, Bahia (9 taxa). On the other hand, Pinheiro et al. (2014), in the Caatinga in Ceará, observed a superior result (27 taxa), while Almeida et al. (2015), in Caatinga preserved in Paraíba, noted a number close to the one found in this study (18 taxonomic groups).

The most representative groups during the 1st period were Isoptera $(34.4 \%)$ and Formicidae (26.7\%), making up more than $60 \%$ of the total sampled. During the 2nd period they were Isoptera
(45.4\%), Coleoptera larvae (15.0\%) and Chilopoda (8.9\%) (Table 2), representing almost $70 \%$ of the total collected, with emphasis for the Isoptera group. The predominance of the Isoptera group during the two collection periods can be attributed to the addition of organic material to the soil, especially in the treatments submitted to management, which presented an increment of the accumulated phytomass (from 26 to $81 \%$ ) in relation to the control (data not shown). The expressive relative density of the Formicidae group during the 1st period corroborates with the results of other studies in the Caatinga region, also in low humidity conditions (NUNES; ARAÚJO FILHO; MENEZES, 2008).

The highest occurrence of Coleoptera larvae during the 2 nd period in relation to the 1 st period is possibly related to the incidence of rainfall (Figure 1), which may have influenced the reproductive cycle of these organisms. We know that the natural periodicity of the physical environment, characterized by its seasons, can regulate the life cycle of organisms in the soil (TOWNSEND; BEGON; HARPER, 2006). These same reasons may explain the higher density of the Chilopoda class during the 2 nd period, since individuals belonging to this taxonomic group depend on the availability of food resources (prey), individuals from other groups (such as oligochaeta and coleoptera larvae), with higher occurrence during the wet season (BARROSO et al., 2001).

Although the CSDap management alone showed significant differences between periods, the total number of individuals showed increases of 300 , 101,19 , and $23 \%$ during the 2 nd period in CSDap, $\mathrm{CR}, \mathrm{CSE}$, and $\mathrm{C}$, respectively (Table 2). It is likely that these results are associated to two factors: first, the greater availability of water, a preponderant condition for the presence of edaphic organisms as a whole, providing greater availability of food resources, and a micro-habitat more favorable to survival and reproduction (DOBLAS-MIRANDA; SANCHEZ-PIÑERO; GONZÁLEZ-MEGÍAS, 2007). The second factor may be related to the increase in the deposition of leaves observed in Caatinga regions during the drought period (MACHADO et al., 2015), which would have caused greater accumulation of burlap on the soil in the transition period between the dry and the rainy season (2nd period) and, consequently, greater humidity and availability of food resources in the soil. 
Table 2. Density of individuals, richness and diversity indexes of the edaphic macrofauna community during two periods of the year (1st period: March 2016 and 2nd period: November 2016) in managed and unmanaged arboreal Caatinga.

\begin{tabular}{|c|c|c|c|c|c|c|c|c|}
\hline \multirow{2}{*}{ Groups/Area } & $\mathrm{CR}$ & CSDap & CSE & $\mathrm{C}$ & $\mathrm{CR}$ & CSDap & CSE & $\mathrm{C}$ \\
\hline & \multicolumn{8}{|c|}{ 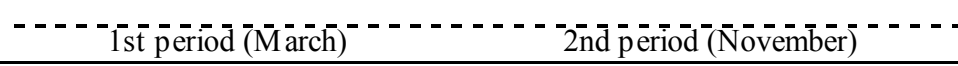 } \\
\hline Araneae & 8 & 4 & 3 & 7 & 2 & 5 & 6 & 11 \\
\hline Archaeognatha & 0 & 1 & 0 & 0 & 0 & 0 & 0 & 0 \\
\hline Blattodea & 0 & 2 & 2 & 5 & 0 & 1 & 3 & 1 \\
\hline Chilopoda & 6 & 5 & 4 & 4 & 11 & 8 & 17 & 20 \\
\hline Coleoptera & 2 & 8 & 8 & 4 & 6 & 13 & 4 & 11 \\
\hline Dermaptera & 0 & 0 & 0 & 0 & 2 & 0 & 1 & 0 \\
\hline Diplopoda & 0 & 0 & 1 & 1 & 0 & 0 & 1 & 1 \\
\hline Diptera & 0 & 1 & 0 & 1 & 0 & 0 & 0 & 0 \\
\hline Formicidae & 10 & 37 & 24 & 30 & 5 & 9 & 5 & 6 \\
\hline Gastropoda & 3 & 1 & 4 & 3 & 2 & 1 & 2 & 1 \\
\hline Heteroptera & 0 & 2 & 0 & 0 & 0 & 0 & 0 & 0 \\
\hline Hymenoptera & 0 & 0 & 9 & 7 & 0 & 0 & 3 & 0 \\
\hline Isopoda & 0 & 0 & 0 & 0 & 4 & 3 & 7 & 5 \\
\hline Isoptera & 0 & 26 & 48 & 56 & $90 \mathrm{a}$ & $124 \mathrm{ab}$ & $37 \mathrm{ab}$ & $36 \mathrm{~b}$ \\
\hline Coleoptera larvae & 3 & 4 & 6 & 10 & $11 \mathrm{~b}$ & $20 \mathrm{ab}$ & $25 \mathrm{ab}$ & $39 \mathrm{a}$ \\
\hline Diptera larvae & 0 & 0 & 0 & 0 & 1 & 0 & 3 & 2 \\
\hline Lepidoptera larvae & 1 & 0 & 0 & 0 & 0 & 0 & 6 & 2 \\
\hline Neuroptera larvae & 0 & 0 & 0 & 0 & 1 & 4 & 1 & 4 \\
\hline Oligochaeta & 0 & 0 & 0 & 0 & 1 & 2 & 4 & 4 \\
\hline Orthoptera & 1 & 1 & 2 & 0 & 1 & 0 & 1 & 4 \\
\hline Pseudoscorpiones & 1 & 2 & 4 & 1 & 0 & 2 & 8 & 8 \\
\hline Scorpiones & 0 & 1 & 2 & 0 & 0 & 0 & 0 & 3 \\
\hline Thysanura & 0 & 1 & 1 & 0 & 3 & 1 & 6 & 1 \\
\hline Ave. density (ind. $\mathrm{m}^{2}$ ) & $35 \mathrm{aA}$ & $96 \mathrm{aB}$ & $118 \mathrm{aA}$ & $129 \mathrm{aA}$ & $140 \mathrm{aA}$ & $193 \mathrm{aA}$ & $140 \mathrm{aA}$ & $159 \mathrm{aA}$ \\
\hline$S$ & 80.7 & 185.6 & 265.8 & 285.2 & 213.2 & 276.9 & 190.5 & 158.7 \\
\hline Total richness & 9 & 15 & 14 & 12 & 14 & 13 & 19 & 18 \\
\hline Average richness & $2.6 \mathrm{aB}$ & $4.2 \mathrm{aA}$ & $5 \mathrm{aB}$ & $2.8 \mathrm{aB}$ & $4.8 \mathrm{aA}$ & $6.0 \mathrm{aA}$ & $7.2 \mathrm{aA}$ & $6.2 \mathrm{aA}$ \\
\hline $\mathrm{H}^{\prime}$ & 2.72 & 2.70 & 2.81 & 2.54 & 2.08 & 2.01 & 3.47 & 3.30 \\
\hline $\mathrm{J}$ & 0.86 & 0.69 & 0.74 & 0.71 & 0.55 & 0.54 & 0.82 & 0.79 \\
\hline
\end{tabular}

Abbreviations: Ave. density (ind $\mathrm{m}^{-2}$ ) - average density. $S$ - standard deviation from average density for $\mathrm{n}=8$. CR - clear cutting, CSDap - selective cutting by minimum diameter, CSE - selective cutting by species, C - unmanaged Caatinga, control. Lowercase letters on the same line compare treatments during a same period and, when they are equal, they do not differ by Kruskal-Wallis test at a $5 \%$ significance. Uppercase letters on the same line compare the periods for a same treatment and, when they are equal, they do not differ by Wilcoxon test at a 5\% significance. H' - Shannon index, J - Pielou equability index.

In relation to the total richness of the groups, the most expressive results during the 1 st period were observed in the selective cutting management (CSDap and CSE) (Table 2), which suggests that the climatic stability of the environments was not affected by the selective cutting level of intervention, possibly because they maintain the soil coverage and, as a result, more comfortable temperature and humidity conditions for edaphic organisms. According to Nunes and Pinto (2012), forest ecosystems which conserve proper atmospheric humidity and temperature, become auspicious environments for the proliferation of organisms. For most managements during the 2 nd period, there was an increase in the number of groups and average richness. The only exception was CSDap, which showed a mild reduction in the number of groups, and maintained the average richness between periods.

For both Shannon index (H') and Pielou index $(J)$, we could observe more expressive values during the 2 nd period in relation to the 1 st period for $\mathrm{CSE}$ and $\mathrm{C}$ managements (Table 2). This variation suggests that the rainy period favored the occurrence 
of a bigger number of groups in these managements. The influence of rainfall on the variation of the edaphic mesofauna Shannon index was also observed by Araújo et al. (2009), in the Caatinga region in the semiarid of Paraíba, and by Marques et al. (2014), in the riparian forest in the state of Minas Gerais. On the other hand, there were reductions in the $\mathrm{H}^{\prime}$ and $\mathrm{J}$ values during the 2 nd period for the $\mathrm{CR}$ and CSDap managements, which may be related to the higher incidence of the Isoptera taxon, in detriment of other groups, and indicates that a larger number of individuals did not necessarily imply in an increased diversity with these managements.

The occurrence, even in different proportions, of the groups of predators Araneae, Chilopoda, and Pseudoscorpiones in all managements and periods (Table 2) indicates that, even when submitted to forest management, the environment maintains the trophic chain functional, as these organisms act in the food chain regulation (CUNHA NETO et al., 2012).

The presence of the Orthoptera and Thysanura groups, characteristic herbivores and decomposers, during both periods of the year in most managements, suggests that the environment presented favorable conditions for their survival, with availability of organic matter: animals (alive, dead, and decomposing), plant residues, seedlings, and fungi (SWIFT et al., 2010; ARAÚJO et al., 2015). The presence of the Coleoptera order during both periods studied indicates a great survival capacity of these organisms in different climate conditions. The big majority of these invertebrates resist against environmental changes, acting on the cycling of nutrients as saprophagous (SOUTO et al., 2008).

The absence of the Blattodea group in the CR management in both periods of the year can be explained by the habitat preference of those insects, that typically shelter in humid places, such as burlap and bark (TEIXEIRA; COUTINHO, 2002). Such condition is less favored by the CR management, since the total removal of trees and shrubs promotes a higher sun incidence on the soil and the absence of continuous burlap supply.

The groups only present during the 2nd period were more sensitive to edaphoclimatic conditions. As an example, we can list the order Isopoda, which is strongly dependent on humid environments (PAOLETTI; HASSALL, 1999); the Neuroptera larvae group, whose choice of nesting sites results from the interaction between rain and temperature (GOTELLI, 1993); and the order Oligoqueta (earthworms), whose activity and depth of occurrence is related to soil temperature and humidity (EDWARDS; BOHLEN, 1996).

The principal component analysis (PCA) of the macrofauna community in the different types of forest management during the 1st period (Figure 2) resulted in eigenvalues of $31.5 \%$ for the horizontal axis (Dim1) and 42.5\% for the vertical axis (Dim2), representing a total variance of $74 \%$. The graphical dispersion showed similarities between CSE and CSDap managements compared to the control (all positioned on the left side of the y axis, opposite to the $\mathrm{CR}$ management). This indicates that the selective cutting ensured greater conservation of the environment, as a result of less management interference, when compared to the $\mathrm{CR}$ (total suppression of the vegetation).

A great part of the organisms associated to the CSDap, CSE and C were detritivores and burlap decomposers (Diplopoda, Isoptera, Orthoptera, Diptera, Formicidae e Coleoptera) (SWIFT et al., 2010). This result suggests that there is a greater abundance of food resources to be decomposed in these treatments, since the detritivores feed on decaying organic matter. The burlap transformers fragment plant debris, making them more accessible to decomposing microorganisms (SWIFT et al., 2010). In turn, we observed that characteristic groups of predators (Chilopoda and Aranae) had a closer association with $\mathrm{CR}$, which can be attributed to a possible food provision, as the result of the vertical vegetation structure elimination, caused by this type of management. Such condition would reduce the availability of shelters and, consequently, make other fauna groups, such as Lepidoptera larvae (also associated to CR management, Figure 2), more vulnerable to the action and dominance of the predators' functional group. 


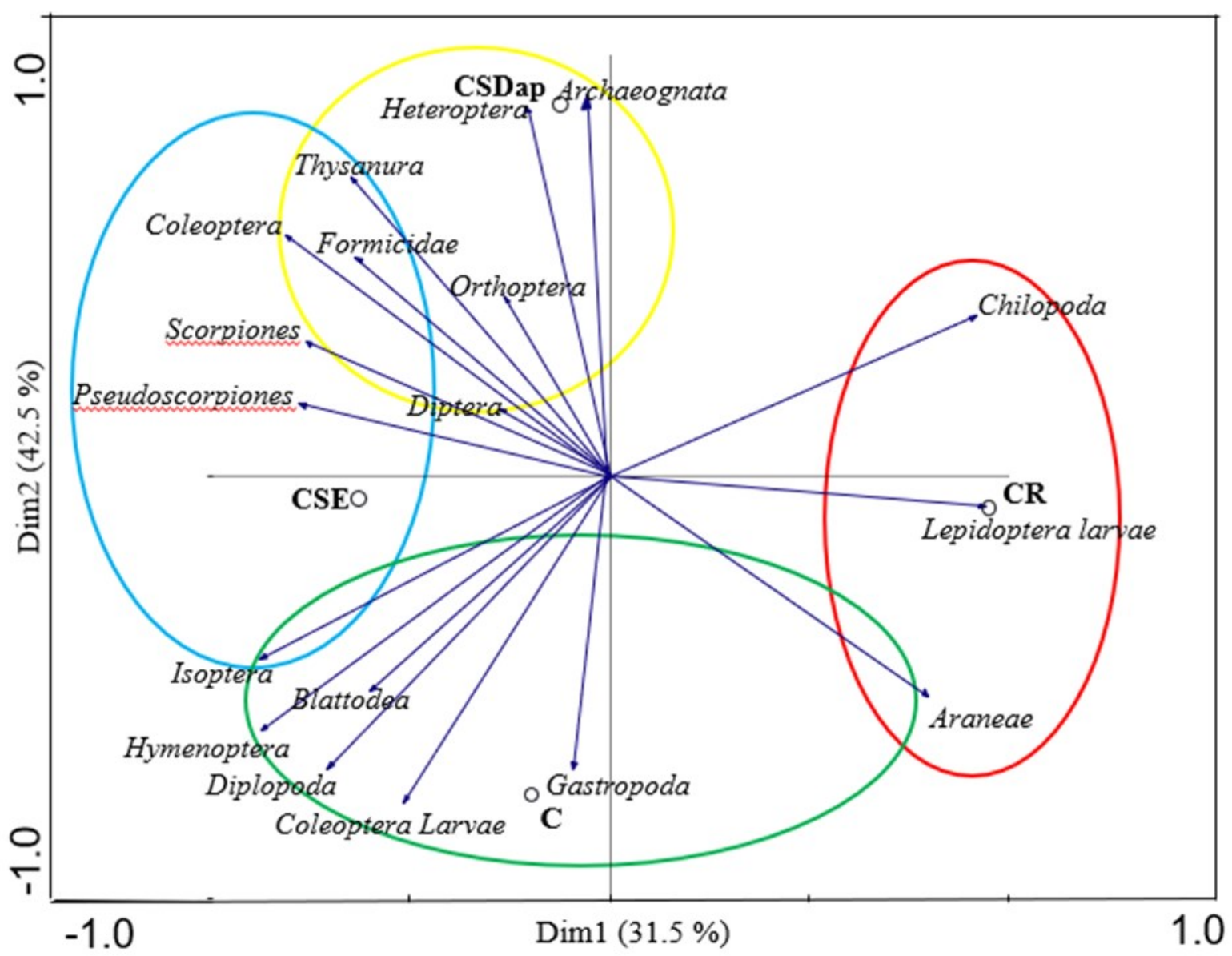

Figure 2. Principal component analysis (PCA) of the edaphic fauna groups during the 1 st period, in managed and unmanaged arboreal Caatinga. CR - clear cutting (red ellipse), CSDap - selective cutting by minimum diameter (yellow ellipse), CSE - selective cutting by species (blue ellipse), C - control (green ellipse).

The PCA from the 2nd period presented responses that differed from the 1 st period (Figure 3). Eigenvalues of $36.8 \%$ for Dim1 and 52\% for Dim2 were reached, totaling $88.8 \%$ explanation for the data variability. The control management was associated to most of the groups identified as typical predators (Chilopoda, Araneae, Scorpiones, and Pseudoscorpiones) and as decomposers (Diplopoda and Orthoptera). Additionally, a clear relationship was observed between the Oligochaeta group and the control management, a group that was absent during the dry season. This result can be attributed to a greater availability and variety of resources in this environment and period. Conserved and preserved areas tend to promote the formation of more diverse burlap, offering variety of food and substrate for the soil fauna. Associated to this, the presence of groups more sensitive to soil and climate conditions, such as Oligochaeta (earthworms), may be related to the microclimate and on how intensely the soil is used, affecting edaphic organisms in general. According to Edwards and Bohlen (1996), the activity and depth inhabited by some species of earthworms are related to the temperature and humidity of the soil, and during unfavorable times they can migrate to the deep regions in search of a more appropriate environment.

The taxa most related to the CSE and CR managements were the detritivores; and with the CSDap were the social insects (Figure 3). The higher association of detritivores with CSE can be explained by the presence of plant residues in several stages of decomposition, since these organisms feed on microparticles of organic matter made available after substrate fragmentation (plant and animal residues) (SWIFT et al., 2010). The association of detritivores (Dermaptera and Isoptera), burlap transformers, with CR during the wet season suggests a specialization in this environment and period for decomposition activity. 


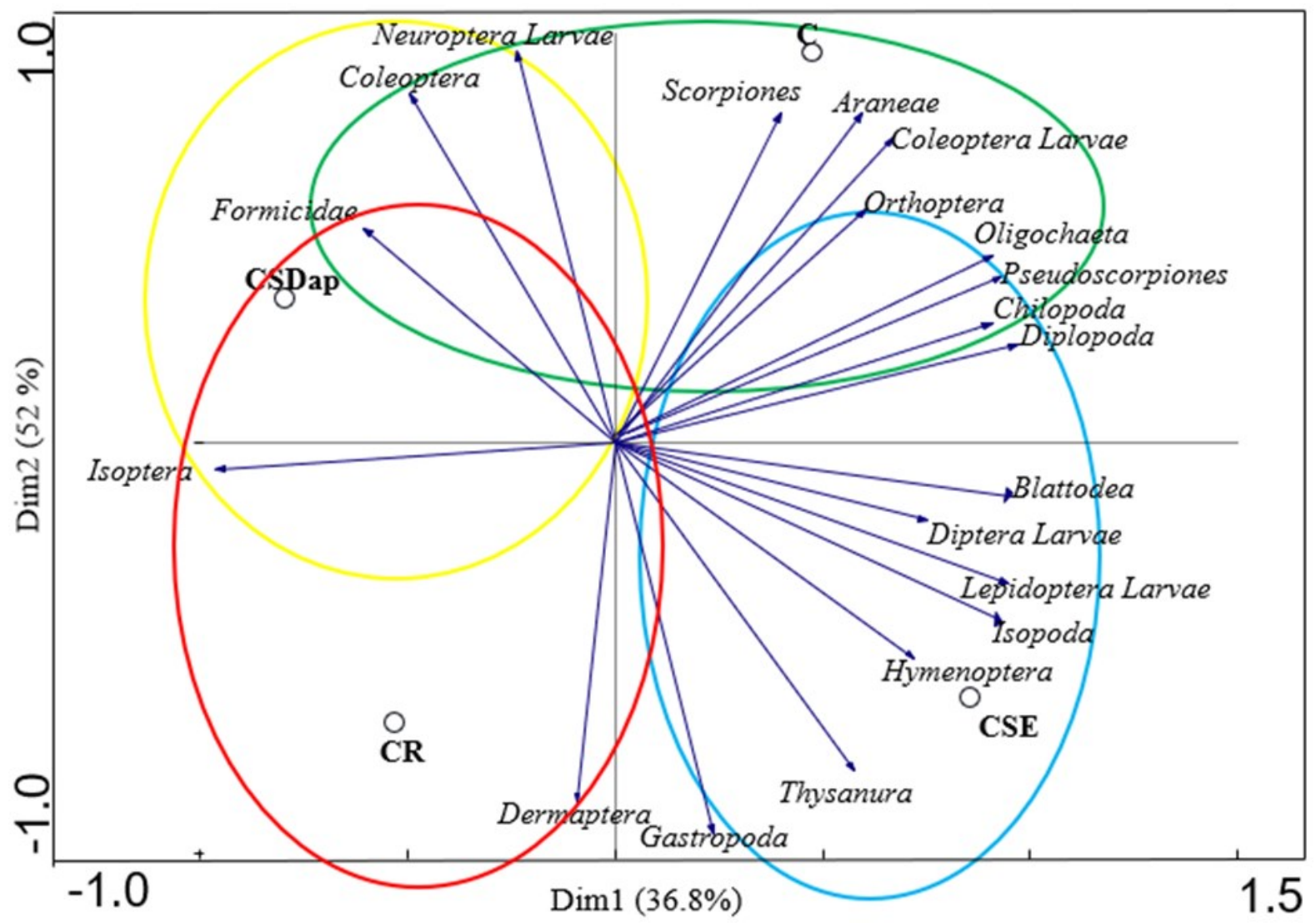

Figure 3. Principal component analysis (PCA) of edaphic fauna groups during the 2nd period, in managed and unmanaged arboreal Caatinga. CR - clear cutting (red ellipse), CSDap - selective cutting by minimum diameter (yellow ellipse), CSE selective cutting by species (blue ellipse), C - control (green ellipse).

The greater association of social insects (ants and termites) with CSDap can indicate a certain level of modification in the environment. According to Silva et al. (2006), when there is a reduction in the diversity of food resources, some groups of the soil macrofauna can establish themselves with great efficiency and dominate the community, being this a quite characteristic behavior of social insects, such as termites.

\section{CONCLUSIONS}

The edaphic macrofauna community shows that selective cutting, which is a more conservative management of the Caatinga, furthers the maintenance of the number of individuals and groups of invertebrates. Among these, selective cutting by species proved to be less impacting to the soil macrofauna, due to more expressive diversity and abundance index values, and the occurrence of more demanding organisms in microclimate conditions, which characterize preserved areas.

The predominant edaphic fauna groups, both in unmanaged as in managed Caatinga, were Isoptera, Formicidae, Chilopoda, and Coleoptera Larvae.

\section{ACKNOWLEDGEMENTS}

To the Conselho Nacional de Desenvolvimento Científico e Tecnológico - CNPq, for granting financial support to the project, and to Fundação de Amparo à Pesquisa do estado da Bahia - FAPESB, for granting a scholarship.

\section{REFERÊNCIAS}

ALMEIDA, M. A. et al. Sazonalidade da macrofauna edafica do Curimatau da Paraiba, Brasil. Ambiencia, v. 11, n. 2, p. 393-407, 2015.

ANDERSON, J. M.; INGRAM, J. S. I. Tropical soil biology and fertility: a handbook of methods. 2 . ed. Wallingford: CAB International, 1993, 265 p.

ARAÚJO A. S. F. D. et al. Soil surface-active fauna in degraded and restored lands of Northeast Brazil. Land Degradation Development, v. 26, n. 1, p. 1-8, 2015.

ARAÚJO, K. D. et al. Influência da precipitação pluvial sobre a mesofauna Invertebrada do solo em 
área de caatinga no Semiárido da Paraíba. Revista Eletrônica do Curso de Geografia, v. 12, s/n., p. 1-12, 2009.

BARETTA, D. et al. Earthworm populations sampled using collection Araucaria angustifolia methods in Atlantic Forests. Scientia Agricola, v. 64 , n. 4, p. 384-392, 2007.

BARROSO, E. et al. Acidentes por centopéias notificados pelo "Centro de informações toxicológicas de Belém”, num período de dois anos. Revista da Sociedade Brasileira Medicina Tropical, v. 34, n. 6, p. 527-530, 2001.

BRASIL, Ministerio da Casa Civil. Lei $\mathbf{n}^{0} \mathbf{1 2 6 5 1}$, de 25 de maio de 2012. Disponivel em: $<\mathrm{http}: / /$ www.planalto.gov.br/ccivil_03/_ato20112014/2012/ lei/112651.htm>. Acesso em: 08 Jan. 2018.

COMITÊ TÉCNICO CIENTÍFICO DA REDE DE MANEJO FLORESTAL DA CAATINGA. Protocolo de medições de parcelas permanentes. Recife, PE: RMFC, 2005. 21 p.

COSTA, L. M.; DRESCHER, M. S. Implications of agricultural management on the epigeic fauna and soil physical properties of a clayey Oxisol. Revista Ceres, v. 65, n. 5, p. 443-449, 2018.

CUNHA NETO, F. V. et al. Soil fauna as an indicator of soil quality in forest stands, pasture and secondary forest. Revista Brasileira de Ciência do Solo, v. 36, n. 5, p. 1407-1417, 2012.

DOBLAS-MIRANDA, E.; SANCHEZ-PIÑERO, F.; GONZÁLEZ-MEGÍAS, A. Soil macroinvertebrate fauna of a Mediterranean arid system: Composition and temporal changes in the assemblage. Soil Biology \& Biochemistry, v. 39, n. 8, p. 1916-1925, 2007.

DONAGEMMA, G. K. et al. Manual de métodos de análise de solo . 2. ed. Rio de Janeiro, RJ: EMBRAPA, 2011. 225 p.

DRUMOND, M. A.; SCHEISTEK, H.; SEIFFARTH, J. A. Caatinga: Um bioma exclusivamente brasileiro e o mais frágil. Revista do Instituto Humanitas Unisinos, v. 7, n. 389, p. 1-60, 2012.

EDWARDS, C. A.; BOHLEN, P. J. Biology and ecology of earthworms. 3. ed. London: Chapman \& Hall; 1996. 422 p.

GOTELLI, N. J. Ant lion zones: causes of highdensity predator aggregations. Ecology, v. 74, n. 1, p. 226-237, 1993.
GUERRA, R. T.; BUENO, C. R.; SCHUBART, H. O. Avaliação preliminar sobre os efeitos da aplicação de herbicidas Paraquat e aração convencional na fauna edáfica do solo na região de Manaus - AM. Acta Amazônica, v. 12, n. 1, p. 7-13, 1982.

HOFFMAN, R. B. et al. Efeito do uso do solo sobre a macrofauna edáfica. Brazilian Journal of Animal and Environmental Research, v. 1, n. 1, p. 125$133,2018$.

LIMA, P. C. F.; LIMA, J. L. S. Composição florísitica e fitossociologia de uma área de Caatinga em Contendas do Sincorá, Bahia, microrregião homogênea da Chapada Diamantina. Acta Botanica Brasilica, v. 12, n. 3, sup., p. 441-450, 1998.

MACHADO, D. L. et al. Fauna edáfica na dinâmica sucessional da Mata Atlântica em floresta estacional semidecidual na bacia do Rio Paraíba do Sul - RJ. Ciência Florestal, v. 25, n. 1, p. 91-106, 2015.

MARCHÃO, R. L. et al. Soil macrofauna under integrated crop-livestock systems in a Brazilian Cerrado Ferralsol. Pesquisa Agropecuária Brasileira, v. 44, n. 8, p. 1011-1020, 2009.

MARTINS, L. et al. Manual Técnico da Vegetação Brasileira. 2. ed. Rio de Janeiro, RJ: IBGE, 2012. $271 \mathrm{p}$.

MARQUES, D. M. et al. Macrofauna edáfica em diferentes coberturas vegetais. Biosciense Journal, v. 30, n. 5 , p. $1588-1597,2014$.

MINISTÉRIO DO MEIO AMBIENTE/INSTITUTO BRASILEIRO DE MEIO AMBIENTE E DOS RECURSOS NATURAIS RENOVÁVEIS - MMA/ IBAMA. Plano de manejo Floresta Nacional Contendas do Sincorá. v 1. Brasília: MMA/ IBAMA, 2006. 132 p.

MINISTÉRIO DO MEIO AMBIENTE - MMA. Caatinga. Disponível em: $<$ http://www.mma.gov.br/ biomas/caatinga $>$. Acesso em: 31 jan. 2018.

MOÇO, M. K. S. et al. Caracterização da fauna edáfica em diferentes coberturas vegetais na região Norte Fluminense. Revista Brasileira de Ciência do Solo, v. 29, n. 4, p. 555-564, 2005.

NUNES, F. P.; PINTO, M. T. C. Decomposição do folhedo em reflorestamento ciliar na bacia hidrográfica do rio São Francisco, Minas Gerais. Cerne, v. 18, n. 3, p. 423-431, 2012.

NUNES, L. A. P. L.; ARAÚJO FILHO, J. A.; MENEZES, R. I. Q. Diversidade da fauna edáfica em solos submetidos a diferentes sistemas de manejo no Semiárido Nordestino. Scientia Agrícola, v. 10, 
n. 1, p. $43-49,2009$.

NUNES, L. A. P. L.; ARAÚJO FILHO, J. A.; MENEZES, R. I. Q. Recolonização da fauna edáfica em áreas de caatinga submetidas a queimadas. Revista Caatinga, v. 21, n. 3, p. 214-220, 2008.

ODUM, E. P.; BARRETT, G. W. Fundamentos de ecologia. 6. ed. São Paulo, SP: CENGAGE, 2011. $612 \mathrm{p}$.

PAOLETTI, M. G.; HASSALL, M. Woodlice (Isopoda: Oniscidea): Their potential for assessing sustainability and use as bioindicators. Agriculture, Ecosystems \& Environment, v. 74, n. 1-3, p. 157$165,1999$.

PIELOU, E. C. Mathematical ecology. New York: Wiley, 1977. $286 \mathrm{p}$.

PINHEIRO, F. J. et al. Caracterizacao da macrofauna edafica na interface solo-serrapilheira em uma area de Caatinga do Nordeste brasileiro. Enciclopedia Biosfera,v. 10, n. 19, p. 2964, 2014.

RUGGIERO, M. A. et al. A Higher Level Classification of All Living Organisms. PLoS ONE, v. 10, n. 4, p. 119-248, 2015.

SCORIZA, R. N.; CORREIA, M. E. F. Fauna do solo como indicadora em fragmentos florestais na Encosta de Morrotes. Floresta e Ambiente, v. 23, n. 4, p. 598-601, 2016.

SILVA, R. F. et al. Macrofauna invertebrada do solo sob diferentes sistemas de produção em Latossolo da região do Cerrado. Pesquisa Agropecuária Brasileira, v. 41, n. 4, p. 697-704, 2006.

SMITH, R. L.; SMITH, T. M. Ecologia. Madrid: Pearson Educación S. A., 2001,776 p.

SOUTO, P. C. et al. Comunidade microbiana e mesofauna edáficas em solo sob Caatinga no semiárido da Paraíba. Revista Brasileira de Ciência do Solo, v. 32, n. 1, p. 151-160, 2008.

SWIFT, M. J. et al. O inventário da biodiversidade biológica do solo: conceitos e orientações gerais. In: MOREIRA, F. M. S., HUISING, E. J., BIGNELL, D. E. (Eds.). Manual de biologia dos solos tropicais: amostragem e caracterização da biodiversidade. Lavras: Editora da UFLA, 2010, v. 1 , cap. 5 , p. 23-41.

TEIXEIRA, R. L.; COUTINHO, E. S. Hábito alimentar de Proceratophrys boiei (Wied) (Amphibia, Anura, Leptodactylidae) em Santa Teresa, Espírito Santo, Sudeste do Brasil. Boletim do Museu de Biologia Mello Leitão, v. 14, s/n., p. 13-20, 2002.

TOWNSEND, C. R.; BEGON, M.; HARPER, J. L. Fundamentos em Ecologia. 2. ed. Porto Alegre, RS: ARTMED, 2006. 592 p. 